\title{
EVALUATION OF AQUACROP PERFORMANCE IN SIMULATING WHEAT AND MAIZE CROPS PRODUCTION IN EGYPT
}

\author{
AMAL ABO EL MAGD ${ }^{1}$, IHAB JNAD ${ }^{2}$, MAZEN NAAMAN ${ }^{2}$ and DIRK RAES ${ }^{3}$ \\ ${ }^{1}$ Agricultural Engineering Research Institute (AEnRI)-Agricultural Research Center (ARC), Egypt \\ ${ }^{2}$ Arab Center for the Studies of Arid Zones and Dry Lands (ACSAD), Syria \\ ${ }^{3}$ Faculty of Bioscience Engineering, KU Leuven University, Belgium
}

Corresponding author: Amal Abo El Maged, irrigation and drainage Systems Department, Agricultural Engineering Research Institute (AEnRI), Agricultural Researcher Center (ARC), Cairo, Egypt. (Email:radwan_3a@yahoo.com)

(Manuscript received 1 August 2018)

\begin{abstract}
$\mathrm{T}$ he objective of this study was to evaluate the performance of the AquaCrop model in simulating the production of wheat and maize crops in old lands in the Nile valley and the Delta region of Egypt, by using fully irrigated system. Multi-year field experimental data from 2000 to 2016 were used to calibrate the model for simulating grain yield under full irrigation conditions. The model performance was evaluated using normalized root mean square error (NRMSE). The best calibrated crop files had $8.7 \%$ and $3.9 \%$ of NRMSE for wheat and maize respectively, for the relationship between the observed and the simulating grain yield. The performance of the model was evaluated to simulate eight irrigation scheduling scenarios for each crop, which may be applied by the farmers. The model reflected a good performance in simulated those scenarios with NRMSE less than $10 \%$. The better simulation results were observed with applying six and seven irrigation events for wheat and maize, respectively. In conclusion, this calibration process is a step to further applications of AquaCrop model as a simulation tool in supporting the agricultural decisions planning, in order to face the current and future challenges of water shortage and irrigation systems improvement.
\end{abstract}

\section{INTRODUCTION}

The Egyptian agriculture is known as one of the agricultural systems characterized by wide variation, complicated structure, intensive applications, and high productivity. One of the most remarkable characters of this system, that almost $95 \%$ of the total 3.4 million hectares of the cultivated area are fully irrigated (MWRI, 2017). At the same time, the Egyptian agriculture is facing numerous challenges, such as water shortage and climate change, that undermine its capacity to sustain food security. In this regard, improving agriculture and irrigation management need to be based on more efficient and profitable use of water to produce more crops. Irrigated agriculture in Egypt could be a clear example for the struggle to improve water productivity under arid conditions. Egypt has one of the most complicated 
irrigation systems covering almost all the agricultural areas along the nation, consuming about $85 \%$ of the total national water resources.

Currently, the irrigated agriculture in Egypt is under serious pressures due to the imbalance between the water resources and demands, poor management, and the weak institutional and infrastructure frameworks (Allam et al., 2005). The irrigation system in Egypt is strongly changed at the recent decades as a result of several emerging key issues, such as land fragmentation, free cropping pattern policy, poor maintenance of the irrigation network, soil salinity problems, water table logging, water logging, excessive water wasting, and energy considerations being affected the poorer farmers and decrease their production and income potential (Soliman et al., 2010 and El-Agha et al., 2011). Furthermore, climate change is addressed as extra expected environmental threat, which is projected to have serious impacts on agricultural production and water use in Egypt.

For producing optimal crop yield by using less water, the design and the application of efficient irrigation strategies and practices requires better understanding of crop response to various degrees of water stress and environmental stress (Domínguez et al., 2011). Crop simulation models are valuable tools for evaluating the potential effects of environmental, biological and management factors on crop growth and development. They have been evaluated and used for many soil and environmental conditions across the world and have been successfully used in yield predictions (Jagtap and Jones, 2002), irrigation planning for crops (Behera and Panda, 2009), optimization of irrigation water use (Bulatewicz et al., 2009, Attaher et al., 2013), and understanding the climate change impacts on various crops (You et al., 2009; Hassanein and Medany, 2007; Khalil et al., 2009; Reidsma et al., 2010; and Ibrahim, et al., 2012).

FAO has been developing a yield-response to water model، "AquaCrop", which simulates attainable yields of the major crops( Steduto et al., 2008). As compared to other crop models, AquaCrop has a significantly smaller number of parameters and a better balance between simplicity, accuracy and robustness. The AquaCrop model is a water-driven crop growth model and it simulates attainable yields of major herbaceous crops as a function of water consumption under rainfed, full, supplemental and deficit irrigation conditions. The daily simulation of crop growth development in AquaCrop is integrated with the daily simulation of soil water balance, which provides a robust and accurate platform for modeling different agricultural management scenarios where water is a limiting factor in crop production, AquaCrop separates evapotranspiration into soil evaporation and crop transpiration while simulating the daily water balance, which is the basis for simulating biomass and 
water productivity, and this differentiates AquaCrop from other crop growth models. This model, the yield is determined by multiplying the aboveground biomass and harvest index $(\mathrm{HI})$.

Since the year 2009, the model has been evaluated and calibrated in a wide number of studies covered a wide range of crops and strategies for arid and semi-arid conditions, and other water scarcity case studies (e.g. ; Salemi et al., 2011; Katerji et al., 2013; Vanuytrecht et al., 2014; Bird et al., 2015; Toumi et al., 2016).

The aim of this study is to present AquaCrop model as an evaluated and calibrated tool, to be used for further studies concerned with the impacts of climate change and water shortage on the productivity of some important food crops in Egypt.

\section{MATERIALS AND METHODS}

Calibration process description:_This study focused on calibrating AquaCrop performance in simulating the production of wheat and maize crops, cultivated in the Nile valley and the Delta region by using fully irrigated system. Since, wheat and maize are important cereal crops occupied about $25 \%$ and $18 \%$ of the cultivated area, respectively (MALR, 2000-2016). The two crops are considered as a main food sources, and contributing by $19 \%$ and $9 \%$ of the total food share per capita (MALR, 2015), respectively. Based on the national records, the average yield of the wheat in old lands is ranged from 6 to 6.5 ton/ha, whereas the average yield of the maize is ranged from 7.5 to 8.5 ton/ha (MALR, 2000-2016), which considered as high productivity compared to the international records.

The full description of the theoretical background and concept of AquaCrop is explained in (Raes et al. 2009). Version 6 (March 2017) of the AquaCrop model has been used in this study to conduct a daily simulation of wheat and maize growth under the cultivation conditions of the old lands in Egypt. The aim of those simulations was to calibrate the AquaCrop model by adjusting the model parameters in order to make the model outputs matches the actual observed outputs of the given location. The model simulated wheat and maize growing cycles, biomass production and yield, based on the local characteristics and physiological parameters of the Egyptian cultivars, and their interaction with the local environmental conditions and farming practices.

The calibration process used an input data sets from the historical data records of Sakha research station ( $31^{\circ} 5^{\prime} 34^{\prime \prime} \mathrm{N}, 30^{\circ} 56^{\prime} 46^{\prime \prime} \mathrm{E}$, and $2 \mathrm{~m}$ above mean sea level), which is following the Agriculture Research Center (ARC) of Egypt and located at Kafer El Shiekh governorate. Sakha location could be considered as a good 
representative to the local conditions of the agriculture system of old lands in the Nile Delta region. So, the calibration process was conducted first by adjusting the crop parameters, and then investigated the effect of different scenarios of irrigation schedule in simulating the crop yield of the wheat and maize.

Climate data inputs:_A daily climate data set of seventeen years, from 2000 to 2016, were used to create the climate file (CLI file) of the AquaCrop model. The data set include the maximum and minimum air temperatures $\left[{ }^{\circ} \mathrm{C}\right]$, and the daily precipitation rates[mm]. The data were collected by the standard Agricultural Meteorological Stations located at Sakha Research Station in Kafr El Sheikh. The climatic records were reviewed and screened for eliminating biases and missing records, before creating the AquaCrop CLI file.

The daily reference evapotranspiration $(E T \circ ; \mathrm{mm} /$ day) data were determined by AquaCrop model by using FAO-Penman-Monteith equation (FAO-PM) was presented in Allen et al. (1998). Table (1) shows the summery of the data set, as a monthly mean of the 17 years daily records of the climatic parameters. The standard file of "MaunaLoa.CO2" was add to the CLI file, in order to represent the concentration of the $\mathrm{CO}_{2}$ in the air during the climate data period.

Table 1 . The mean monthly climatic parameters of years $2000-2016$, of Sakha station.

\begin{tabular}{|c|c|c|c|c|}
\hline Month & $\begin{array}{c}\text { Mean monthly } \\
\text { Tmin }\left[{ }^{\circ} \mathrm{C}\right]\end{array}$ & $\begin{array}{c}\text { Mean monthly } \\
\operatorname{Tmax}\left[{ }^{\circ} \mathrm{C}\right]\end{array}$ & $\begin{array}{c}\text { Total monthly } \\
\text { precipitation } \\
{[\mathrm{mm}]}\end{array}$ & $\begin{array}{c}\text { Mean monthly } \\
\text { Eto }[\mathrm{mm}]\end{array}$ \\
\hline Jan & 9.3 & 18.6 & 56.3 & 2.4 \\
\hline Feb & 9.6 & 19.4 & 29.3 & 3.0 \\
\hline March & 11.8 & 21.7 & 7.3 & 4.0 \\
\hline Apr & 14.3 & 24.6 & 2.0 & 5.0 \\
\hline May & 17.6 & 27.2 & 1.1 & 5.6 \\
\hline Jun & 21.5 & 29.4 & 0.1 & 5.8 \\
\hline Jul & 23.9 & 30.9 & 0.2 & 5.9 \\
\hline Aug & 24.4 & 31.4 & 0.0 & 5.6 \\
\hline Sept & 22.3 & 30.5 & 0.6 & 5.2 \\
\hline Oct & 19.0 & 27.8 & 15.6 & 4.2 \\
\hline Nov & 15.1 & 24.2 & 30.3 & 3.1 \\
\hline Dec & 10.9 & 20.2 & 53.3 & 2.4 \\
\hline
\end{tabular}


Soil data inputs: The soil texture that associated with the characterization of waterterrestrial relationships, is one of the main inputs of the AquaCrop model. Table (2) shows a historical data set for the required soil properties at Sakha location, which was recorded by Fawzi (2009). The data set included soil texture components [\%], class, bulk density $\left[\mathrm{g} / \mathrm{cm}^{3}\right]$, field capacity [FC; vol. \%], permanent wilting point [PWP; vol. \%], and the available water content [vol. \%] for 5 soil layers of $20 \mathrm{~cm}$ thickness for each, and up to $100 \mathrm{~cm}$ depth from soil surface.

Additionally, the soil saturation [Sat \%] and the saturated hydraulic conductivity [Ksat, $\mathrm{mm} / \mathrm{day}$ ], are other soil parameters required to create the soil file (SOL file) of the AquaCrop model, and in this study the values of those parameters were not available in the historical data records, and calculated by using SPAW, soilwater characteristics module (Saxton, 1985 and Saxton and Willey. 2006).

Table 2. Soil mechanical and the soil-water relationships properties of the SakhaKafer El Shiekh governorate.

\begin{tabular}{|c|c|c|c|c|c|c|c|c|c|c|}
\hline \multirow{2}{*}{$\begin{array}{l}\text { Depth } \\
{[\mathrm{cm}]}\end{array}$} & \multicolumn{3}{|c|}{ Soil texture } & \multirow{2}{*}{ Class } & \multirow{2}{*}{$\begin{array}{c}\text { Bulk } \\
\text { Density } \\
{\left[\mathrm{g} / \mathrm{cm}^{3}\right]}\end{array}$} & \multirow{2}{*}{ FC \% } & \multirow{2}{*}{ PWP \% } & \multirow{2}{*}{$\begin{array}{l}\text { Available } \\
\text { water } \%\end{array}$} & \multirow{2}{*}{$\begin{array}{l}\text { Sat }^{*} \\
\%\end{array}$} & \multirow{2}{*}{$\begin{array}{c}\text { Ksat }^{*} \\
{[\mathrm{~mm} / \text { day }]}\end{array}$} \\
\hline & $\begin{array}{c}\text { Clay } \\
\%\end{array}$ & $\begin{array}{l}\text { Silt } \\
\%\end{array}$ & $\begin{array}{c}\text { Sand } \\
\% \\
\end{array}$ & & & & & & & \\
\hline $0-20$ & 38.3 & 39.9 & 21.8 & Clay loam & 1.36 & 36.9 & 20.0 & 16.9 & 49.5 & 95.8 \\
\hline $20-40$ & 41.2 & 38.0 & 20.8 & Clay & 1.33 & 37.9 & 22.3 & 15.6 & 50.0 & 79.2 \\
\hline $40-60$ & 48.2 & 33.0 & 18.8 & Clay & 1.29 & 40.8 & 25.1 & 15.7 & 50.9 & 48.7 \\
\hline $60-80$ & 52.2 & 32.6 & 15.2 & Clay & 1.27 & 43.1 & 25.5 & 17.6 & 52.2 & 46.3 \\
\hline $80-100$ & 56.2 & 30.4 & 13.4 & Clay & 1.25 & 44.5 & 27.1 & 17.4 & 52.9 & 37.9 \\
\hline
\end{tabular}

*saturation [Sat \%] and saturated hydraulic conductivity [Ksat, mm/day] are calculated by using SPAW, soil-water characteristics module.

Groundwater data inputs:_Groundwater parameters are among the important parameters to define the simulation environment of AquaCrop, especially for simulating the soil-water balance process. In this study, the groundwater level is considered as $2.8 \mathrm{~m}$ depth from the soil surface, reference to the mean of the historical records of Sakha location.

Crop data inputs:_The crop parameters were collected from the historical records of Sakha station, of two important and widely speared cultivars at old lands in Egypt, of "Giza 168" cultivar for wheat crop, and "single hybrid 10" cultivar for maize crop. Table (3) shows the basic non-conservative parameters for each crop, required for adjusting crop files (CRO file) of AquaCrop in the calibration process. Furthermore, the actual average crop yields of the simulated crops, for the same climatic period of the 
calibration process, are shown in Fig. (1), with an overall average yield of 6.350 ton/ha for wheat, and 8.760 ton/ha for maize. Heat units, expressed in growing degree-days (GDD), can be used in AquaCrop to describe crop development. With this method, the duration of a process or the time required to reach a particular stage is expressed in GDD ( ${ }^{\circ} \mathrm{C}$ day) instead of number of days. Based on the parameters ranges listed in Table (3), seven crop files for each crop, were generated from the standard files "WheatGDD.CRO" and "MaizeGDD.CRO". The adjusted crop cycle parameter values of each file are listed in Tables (4) and (5). The "carbon sink strength" value was adjusted to " $0 \%$ " of all files in order to reduce the overrated effect of plant response to the increase in $\mathrm{CO}_{2}$ levels. Additionally, the plant response to soil fertility was automatically calibrated for all the generated crop files, at soil fertility level of "near optimal". After the parameters adjustment, all the evaluated crop files were run under "growing degree-days" mode.

Table 3. Crop growth cycle and parameters used in the calibration process of AquaCrop.

\begin{tabular}{|c|c|c|}
\hline Parameters & wheat & Maize \\
\hline Cultivar & Giza 168 & Single Hybrid 10 \\
\hline Growing season & Winter & Summer \\
\hline Date of planting & $\begin{array}{l}\text { Mid-November to the first week of } \\
\text { December }\end{array}$ & Second half of May \\
\hline Planting system & 300 plants/m² (200 kg seed / ha) & $\begin{array}{l}60-75 \mathrm{~cm} \text { between furrows, with } 30 \mathrm{~cm} \\
\text { between plants on the same furrow. }\end{array}$ \\
\hline $\begin{array}{l}\text { Number of days from sowing to } \\
\text { emergence }\left[\mathrm{CC}_{0}\right]\end{array}$ & 7- 15 & $10-15$ \\
\hline $\begin{array}{l}\text { Number of days from sowing to } \\
\text { flowering }\end{array}$ & $90-98$ & $65-75$ \\
\hline $\begin{array}{l}\text { Number of days from sowing to } \\
\text { max canopy }\left[\mathrm{CC}_{\mathrm{x}}\right]\end{array}$ & $90-95$ & $75-80$ \\
\hline $\begin{array}{l}\text { The percentage of maximum } \\
\text { canopy cover }\left[\mathrm{CC}_{\mathrm{x}}\right]\end{array}$ & Up to 95 & $90-95$ \\
\hline $\begin{array}{l}\text { Number of days from sowing to } \\
\text { starting of senescence }\end{array}$ & $100-135$ & $85-95$ \\
\hline $\begin{array}{l}\text { Number of days from sowing to } \\
\text { maturity }\end{array}$ & 145 & $100-120$ \\
\hline $\begin{array}{l}\text { Number of days from sowing to } \\
\text { harvest }\end{array}$ & $160-175$ & $115-125$ \\
\hline $\begin{array}{l}\text { Number of days of flowering } \\
\text { stage }\end{array}$ & $10-15$ & $10-15$ \\
\hline $\begin{array}{l}\text { Number of days from sowing to } \\
\text { max rooting depth }\end{array}$ & $75-80$ & $60-75$ \\
\hline $\begin{array}{l}\text { Maximum effective rooting depth } \\
\text { (m) }\end{array}$ & $0.6-0.8$ & $0.7-0.9$ \\
\hline Reference harvest index[HI; \%] & $36-39$ & $42-48$ \\
\hline Response to stresses. & $\begin{array}{l}\text { Moderate tolerant to water and } \\
\text { salinity stresses in all growth } \\
\text { stages, excluding flowering stage }\end{array}$ & $\begin{array}{l}\text { Sensitive to water stress especially } \\
\text { during flowering stage }\end{array}$ \\
\hline
\end{tabular}




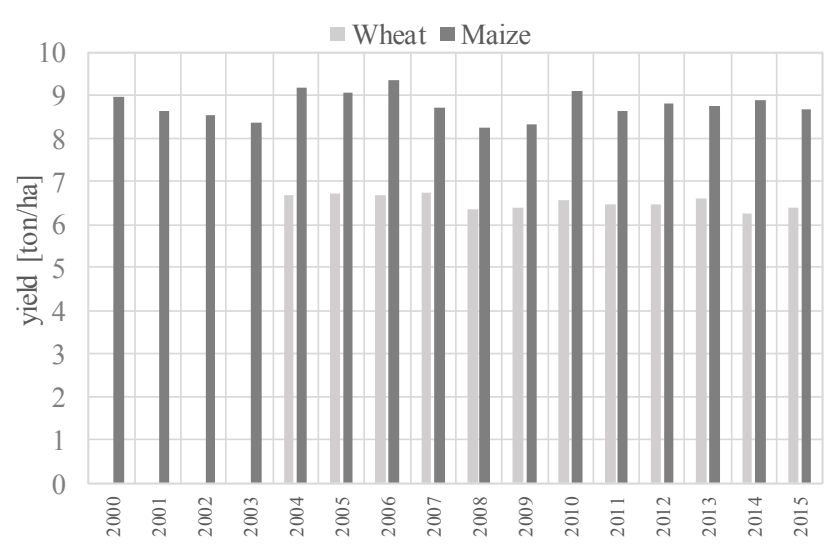

Fig. 1. The average crop yield of wheat (Giza 168) from 2004 to 2015 and maize (single hybrid 10), produced in old lands at kfer El Shiekh governorate, of years 2000- 2015

Table 4. The adjusted crop parameters in the generated crop files, for wheat crop calibration

\begin{tabular}{|c|c|c|c|c|c|c|c|}
\hline Parameters & Wh_cal1 & Wh_cal2 & Wh_cal3 & Wh_cal4 & Wh_cal5 & Wh_cal6 & Wh_cal7 \\
\hline Date of planting & \multicolumn{7}{|c|}{15 November } \\
\hline Plants density & \multicolumn{7}{|c|}{3 million plants/ha } \\
\hline $\begin{array}{l}\text { Number of days from } \\
\text { sowing to emergence } \\
{\left[\mathrm{CC}_{0}\right]}\end{array}$ & 7 & 7 & 9 & 9 & 12 & 12 & 12 \\
\hline $\begin{array}{l}\text { The percentage of } \\
\text { maximum canopy cover } \\
{\left[\mathrm{CC}_{\mathrm{x}}\right]}\end{array}$ & \multicolumn{7}{|c|}{95} \\
\hline $\begin{array}{l}\text { Number of days from } \\
\text { sowing to max canopy } \\
{\left[C_{x}\right]}\end{array}$ & 90 & 90 & 92 & 92 & 95 & 95 & 91 \\
\hline $\begin{array}{l}\text { Number of days from } \\
\text { sowing to flowering }\end{array}$ & 93 & 93 & 95 & 95 & 98 & 98 & 85 \\
\hline $\begin{array}{l}\text { Number of days from } \\
\text { sowing to starting of } \\
\text { senescence }\end{array}$ & \multicolumn{7}{|c|}{106} \\
\hline $\begin{array}{l}\text { Number of days from } \\
\text { sowing to maturity }\end{array}$ & \multicolumn{7}{|c|}{145} \\
\hline $\begin{array}{l}\text { Number of days of } \\
\text { flowering stage }\end{array}$ & 9 & 9 & 10 & 10 & 12 & 12 & 15 \\
\hline $\begin{array}{l}\text { Number of days from } \\
\text { sowing to max rooting } \\
\text { depth }\end{array}$ & 75 & 75 & 77 & 77 & 80 & 80 & 76 \\
\hline $\begin{array}{l}\text { Maximum effective } \\
\text { rooting depth }(\mathrm{m})\end{array}$ & 0.60 & 0.60 & 0.70 & 0.70 & 0.80 & 0.80 & 0.80 \\
\hline $\begin{array}{l}\text { Reference harvest } \\
\text { index[HI; \%] }\end{array}$ & 36 & 39 & 36 & 39 & 36 & 39 & 39 \\
\hline
\end{tabular}


Table 5. The adjusted crop parameters in the generated crop files, for maize crop calibration

\begin{tabular}{|c|c|c|c|c|c|c|c|}
\hline Parameters & Mz_cal1 & $\mathrm{Mz} \_\mathrm{cal} 2$ & Mz_cal3 & $\mathrm{Mz}$ _cal4 & Mz_cal5 & Mz_cal6 & Mz_cal7 \\
\hline Date of planting & \multicolumn{7}{|c|}{15 May } \\
\hline Plants density & \multicolumn{7}{|c|}{44444 plant / hectare } \\
\hline $\begin{array}{l}\text { Number of days from } \\
\text { planting to emergence } \\
\left.\left[\mathrm{CC}_{0}\right]\right]\end{array}$ & 10 & 10 & 10 & 15 & 15 & 15 & 16 \\
\hline $\begin{array}{l}\text { The percentage of } \\
\text { maximum canopy cover } \\
{\left[\mathrm{CC}_{\mathrm{x}}\right]}\end{array}$ & \multicolumn{7}{|c|}{95} \\
\hline $\begin{array}{l}\text { Number of days from } \\
\text { planting to max canopy } \\
{\left[\mathrm{CC}_{\mathrm{x}}\right]}\end{array}$ & 75 & 75 & 75 & 75 & 75 & 75 & 79 \\
\hline $\begin{array}{l}\text { Number of days from } \\
\text { planting to flowering }\end{array}$ & 65 & 65 & 65 & 70 & 70 & 70 & 75 \\
\hline $\begin{array}{l}\text { Number of days from } \\
\text { planting to starting of } \\
\text { senescence }\end{array}$ & 85 & 85 & 85 & 90 & 90 & 95 & 95 \\
\hline $\begin{array}{l}\text { Number of days from } \\
\text { planting to maturity }\end{array}$ & 100 & 100 & 100 & 110 & 110 & 115 & 117 \\
\hline $\begin{array}{l}\text { Number of days of } \\
\text { flowering stage }\end{array}$ & 15 & 15 & 15 & 15 & 15 & 15 & 16 \\
\hline $\begin{array}{l}\text { Number of days from } \\
\text { planting to max rooting } \\
\text { depth }\end{array}$ & 60 & 60 & 60 & 70 & 70 & 70 & 75 \\
\hline $\begin{array}{l}\text { Maximum effective rooting } \\
\text { depth }(m)\end{array}$ & 0.70 & 0.70 & 0.70 & 0.90 & 0.90 & 0.90 & 0.90 \\
\hline $\begin{array}{l}\text { Reference harvest } \\
\text { index[HI; \%] }\end{array}$ & 42 & 45 & 48 & 42 & 45 & 48 & 45 \\
\hline
\end{tabular}

Irrigation management inputs:_In order to calibrate the model by adjusting only the crop parameters, two irrigation practices and management files (IRR file) for wheat and maize were generated based on the irrigation records of the demonstration fields at Sakha location. Those records present the commonly best irrigation practices applied by the farmers in the Nile Delta region. The generated IRR file of Wheat crop include the irrigation system as "border surface irrigation", with six applications per season, 26 days' intervals between applications, and the last application added before the harvesting by 20 days. The application depth is ranged from 60 to $100 \mathrm{~mm}$, with a total irrigation amount of $480 \mathrm{~mm} /$ season. Whereas, the generated IRR file for maize crop include the irrigation system as "furrow surface irrigation", with seven applications per season, 15 days' intervals between applications, and the last application added before the harvesting by 25 days. The application depth is ranged from 90 to $120 \mathrm{~mm}$, with a total irrigation amount of $750 \mathrm{~mm} /$ season. The maize crop had an off season irrigation before the planting date by 15 days, with $120 \mathrm{~mm}$ application depth. 

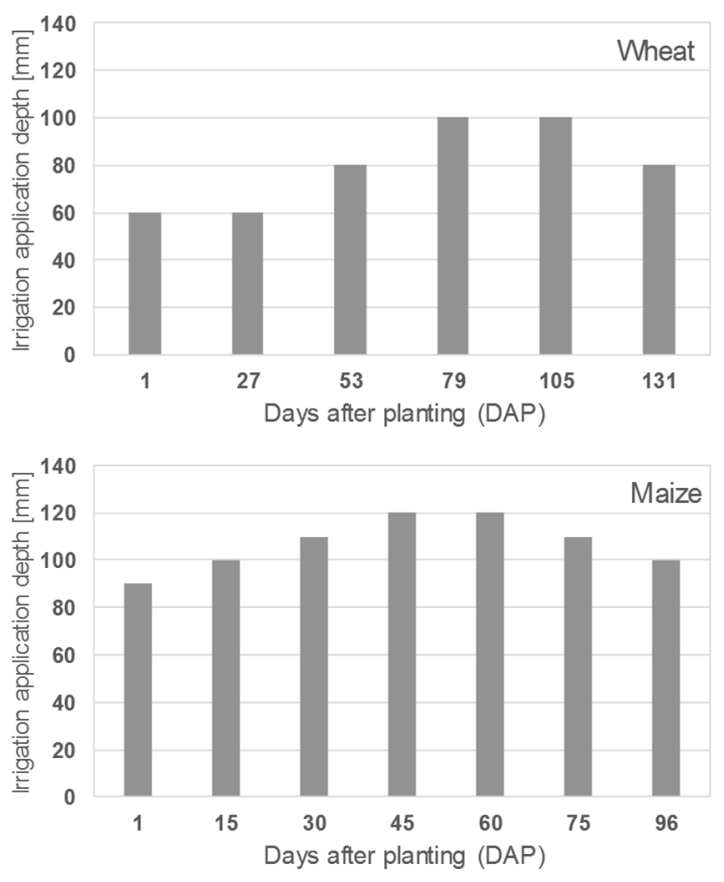

Fig. 2. Irrigation applications applied in the AquaCrop irrigation file (IRR file) for wheat and maize simulations

Under different circumstances, the farmers may apply different irrigation schedules, that the variations in irrigation depth are difficult to apply under surface irrigation systems. It is also very confusing for the farmers to change the schedule all the time. Therefore, it is often sufficient to estimate the irrigation schedule and keeping the irrigation depth and the interval constant over the growing season as much as possible. For this reason, after the calibration of the model by adjusting the crop parameters, several irrigation schedule scenarios (that may be applied by the farmers under different circumstances) were investigated, aiming to understand the effect of the different options of irrigation schedule on the crop yield simulation. Tables (6) and (7) show eight supposed scenarios of irrigation scheduling of wheat and maize, with the irrigation application amounts (App; $\mathrm{mm}$ ), the intervals between the applications, and the time of adding each application by the days after planting (DAP). The scenarios include the number of the irrigation events for each crop, the type of the interval and the application as varied or fixed. It should be noted that, scenarios "Wh_Irr7" and "Mz_Irr6" include the same schedule used in the previous step of model calibration, as shown in Figure (2). Furthermore, the AquaCrop simulations of this investigation used the best calibrated crop files of wheat and maize, which are resulted from the first part of the calibration. 
Table 6. the irrigation scenarios for wheat crop

\begin{tabular}{|c|c|c|c|c|c|c|c|c|}
\hline Scenario name & Description & & & & & & & \\
\hline \multirow[t]{3}{*}{ Wh_Irr1 } & \multirow{3}{*}{$\begin{array}{l}\text { 5 events } \\
\text { Varied interval } \\
\text { Varied application } \\
480 \mathrm{~mm} / \text { season }\end{array}$} & DAP & 1 & 35 & 75 & 105 & 130 & \\
\hline & & App [mm] & 65 & 65 & 90 & 130 & 130 & \\
\hline & & Interval [days] & 34 & 40 & 30 & 25 & & \\
\hline \multirow[t]{3}{*}{ Wh_Irr2 } & \multirow{3}{*}{$\begin{array}{l}\quad 5 \text { events } \\
\text { Varied interval } \\
\text { Fixed application } \\
480 \mathrm{~mm} / \text { season }\end{array}$} & DAP & 1 & 40 & 75 & 105 & 131 & \\
\hline & & App [mm] & 96 & 96 & 96 & 96 & 96 & \\
\hline & & Interval [days] & 39 & 35 & 30 & 26 & & \\
\hline \multirow[t]{3}{*}{ Wh_Irr3 } & \multirow{3}{*}{$\begin{array}{c}5 \text { events } \\
\text { Fixed interval } \\
\text { Varied application } \\
480 \mathrm{~mm} / \text { season }\end{array}$} & DAP & 1 & 34 & 67 & 100 & 133 & \\
\hline & & App [mm] & 65 & 65 & 90 & 130 & 130 & \\
\hline & & Interval [days] & 33 & 33 & 33 & 33 & & \\
\hline \multirow[t]{3}{*}{ Wh_Irr4 } & \multirow{3}{*}{$\begin{array}{l}5 \text { events } \\
\text { Fixed interval } \\
\text { Fixed application } \\
480 \mathrm{~mm} / \text { season }\end{array}$} & DAP & 1 & 34 & 67 & 100 & 133 & \\
\hline & & App [mm] & 96 & 96 & 96 & 96 & 96 & \\
\hline & & Interval [days] & 33 & 33 & 33 & 33 & & \\
\hline \multirow[t]{3}{*}{ Wh_Irr5 } & \multirow{3}{*}{$\begin{array}{c}6 \text { events } \\
\text { Varied interval } \\
\text { Varied application } \\
480 \mathrm{~mm} / \text { season }\end{array}$} & DAP & 1 & 25 & 52 & 75 & 105 & 131 \\
\hline & & App [mm] & 60 & 60 & 80 & 100 & 100 & 80 \\
\hline & & Interval [days] & 24 & 27 & 23 & 30 & 26 & \\
\hline \multirow[t]{3}{*}{ Wh_Irr6 } & \multirow{3}{*}{$\begin{array}{l}6 \text { events } \\
\text { Varied interval } \\
\text { Fixed application } \\
480 \mathrm{~mm} / \text { season }\end{array}$} & DAP & 1 & 25 & 52 & 75 & 108 & 131 \\
\hline & & App [mm] & 80 & 80 & 80 & 80 & 80 & 80 \\
\hline & & Interval [days] & 24 & 27 & 23 & 33 & 23 & \\
\hline \multirow[t]{3}{*}{ Wh_Irr7 } & \multirow{3}{*}{$\begin{array}{c}6 \text { events } \\
\text { Fixed interval } \\
\text { Varied application } \\
480 \mathrm{~mm} / \text { season }\end{array}$} & DAP & 1 & 27 & 53 & 79 & 105 & 131 \\
\hline & & App [mm] & 60 & 60 & 80 & 100 & 100 & 80 \\
\hline & & Interval [days] & 26 & 26 & 26 & 26 & 26 & \\
\hline \multirow[t]{3}{*}{ Wh_Irr8 } & \multirow{3}{*}{$\begin{array}{c}6 \text { events } \\
\text { Fixed interval } \\
\text { Fixed application } \\
480 \mathrm{~mm} / \text { season }\end{array}$} & DAP & 1 & 27 & 53 & 79 & 105 & 131 \\
\hline & & App [mm] & 80 & 80 & 80 & 80 & 80 & 80 \\
\hline & & Interval [days] & 26 & 26 & 26 & 26 & 26 & \\
\hline
\end{tabular}


Table 7. irrigation scenarios for maize crop

\begin{tabular}{|c|c|c|c|c|c|c|c|c|c|}
\hline Scenario name & Description & & & & & & & & \\
\hline \multirow[t]{3}{*}{ Mz_Irr1 } & \multirow{3}{*}{$\begin{array}{c}6 \text { events } \\
\text { Fixed interval } \\
\text { Fixed application } \\
720 \mathrm{~mm} / \text { season }\end{array}$} & DAP & 1 & 20 & 40 & 60 & 80 & 96 & \\
\hline & & App [mm] & 120 & 120 & 120 & 120 & 120 & 120 & \\
\hline & & Interval [days] & 19 & 20 & 20 & 20 & 16 & & \\
\hline \multirow[t]{3}{*}{ Mz_Irr2 } & \multirow{3}{*}{$\begin{array}{c}6 \text { events } \\
\text { Fixed interval } \\
\text { Varied application } \\
660 \mathrm{~mm} / \text { season }\end{array}$} & DAP & 1 & 20 & 40 & 60 & 80 & 96 & \\
\hline & & App [mm] & 90 & 110 & 120 & 120 & 110 & 110 & \\
\hline & & Interval [days] & 19 & 20 & 20 & 20 & 16 & & \\
\hline \multirow[t]{3}{*}{ Mz_Irr3 } & \multirow{3}{*}{$\begin{array}{c}6 \text { events } \\
\text { Varied interval } \\
\text { Fixed application } \\
720 \mathrm{~mm} / \text { season }\end{array}$} & DAP & 1 & 15 & 40 & 55 & 70 & 95 & \\
\hline & & App [mm] & 120 & 120 & 120 & 120 & 120 & 120 & \\
\hline & & Interval [days] & 14 & 25 & 15 & 15 & 25 & & \\
\hline \multirow[t]{3}{*}{ Mz_Irr4 } & \multirow{3}{*}{$\begin{array}{c}6 \text { events } \\
\text { Varied interval } \\
\text { Varied application } \\
660 \mathrm{~mm} / \text { season }\end{array}$} & DAP & 1 & 15 & 40 & 55 & 70 & 95 & \\
\hline & & App [mm] & 90 & 110 & 120 & 120 & 110 & 110 & \\
\hline & & Interval [days] & 14 & 25 & 15 & 15 & 25 & & \\
\hline \multirow[t]{3}{*}{ Mz_Irr5 } & \multirow{3}{*}{$\begin{array}{c}7 \text { events } \\
\text { Fixed interval } \\
\text { Fixed application } \\
840 \mathrm{~mm} / \text { season }\end{array}$} & DAP & 1 & 15 & 30 & 45 & 60 & 75 & 96 \\
\hline & & App [mm] & 120 & 120 & 120 & 120 & 120 & 120 & 120 \\
\hline & & Interval [days] & 14 & 15 & 15 & 15 & 15 & 21 & \\
\hline \multirow[t]{3}{*}{ Mz_Irr6 } & \multirow{3}{*}{$\begin{array}{c}7 \text { events } \\
\text { Fixed interval } \\
\text { Varied application } \\
750 \mathrm{~mm} / \text { season }\end{array}$} & DAP & 1 & 15 & 30 & 45 & 60 & 75 & 96 \\
\hline & & App [mm] & 90 & 100 & 110 & 120 & 120 & 110 & 100 \\
\hline & & Interval [days] & 14 & 15 & 15 & 15 & 15 & 21 & \\
\hline \multirow[t]{3}{*}{ Mz_Irr7 } & \multirow{3}{*}{$\begin{array}{c}7 \text { events } \\
\text { Varied interval } \\
\text { Fixed application } \\
840 \mathrm{~mm} / \text { season }\end{array}$} & DAP & 1 & 10 & 25 & 45 & 60 & 70 & 95 \\
\hline & & App [mm] & 120 & 120 & 120 & 120 & 120 & 120 & 120 \\
\hline & & Interval [days] & 9 & 15 & 20 & 15 & 10 & 25 & \\
\hline \multirow[t]{3}{*}{ Mz_Irr8 } & \multirow{3}{*}{$\begin{array}{c}7 \text { events } \\
\text { Varied interval } \\
\text { Varied application } \\
750 \mathrm{~mm} / \text { season }\end{array}$} & DAP & 1 & 10 & 25 & 45 & 60 & 70 & 95 \\
\hline & & App [mm] & 90 & 100 & 110 & 120 & 120 & 110 & 100 \\
\hline & & Interval [days] & 9 & 15 & 20 & 15 & 10 & 25 & \\
\hline
\end{tabular}

Field management inputs: For both wheat and maize, a "very good" fertilization level was considered in field management parameters of the simulation. The relative cover of the weeds was less than $5 \%$ for wheat and $0 \%$ for maize.

Statistical evaluation:Two indicators were used to evaluate the ability of the model to simulate crop yield, to determine the best crop parameters according to the comparison between predicted and observed dataset under the local conditions. And the statistical indicators that were used as follows:

Root Mean Square Error (RMSE)

$$
R M S E=\sqrt{\frac{\sum\left(Y_{P}-Y_{O}\right)^{2}}{n}}
$$

Normalized Root Mean Square Error (NRMSE)

$$
N R M S E=\frac{1}{\overline{Y_{O}}} \sqrt{\frac{\sum\left(Y_{P}-Y_{O}\right)^{2}}{n}}
$$

Where $\left[Y_{p}\right]$ represents the predicted yield from the simulation, $\left[Y_{0}\right]$ represents the observed yields, $\left[\overline{Y_{O}}\right]$ represents the mean of the observed yields, [n] represents the 
number of the year of the observations and simulations. In general, the simulation is better when the RMSE value is closer to zero, and the simulation can be considered excellent if the NRMSE is less than $10 \%$, good for $10-20 \%$, average quality is $20-30 \%$, and bad if the error value Greater than $30 \%$.

\section{RESULTS AND DISCUSSION}

\section{The calibration of the AquaCrop model by adjusting the crop parameters:}

Figures (3) and (4) shows the results of the calibration process of AquaCrop model, for wheat and maize based on the adjusting crop growth cycle and parameters. The crop files titled "Wh_cal7" and "Mz_cal7" gave the best calibration results, for wheat and maize, respectively, as they had the best crop parameters adjustment combinations to represent the crops growth cycles. The case of "Wh_cal7" had an RMSE value of 0.570 ton/ha, and excellent NRMSE of $8.73 \%$. As well as, the RMSE value of "Mz_cal7" case was 0.338 ton/ha, with an excellent NRMSE of $3.86 \%$.

Reference to the parameters in Table (4) and the obtained results, the relationship between the observed and simulated yields of wheat was improved by the increase in the flowering stage period from 9 to 15 days, and the increase of the effective rooting depth up to $0.8 \mathrm{~m}$. For the same growth cycle, the higher harvest index gave the better simulation results, and the best simulation result was observed with a harvest index value of $39 \%$.

For the maize crop simulation, the relationship between the observed and simulated yields was improved by the increase of the growth cycle from sowing to maturity, from 100 to 117 days. Additionally, the increase in the period from sowing to flowering up to 75 days and flowring period to 16 days, coupled with an effective rooting depth up to $0.9 \mathrm{~m}$ gave the best simulation result. The best simulation result of maize crop, was observed with a harvest index value of $45 \%$.

The effect of irrigation schedule in the crop yield simulation: Building on the previous calibration of the crop files of the AquaCrop model, the effect of the irrigation schedule in the crop yield simulation was investigated using the same field data of Sakha region during the period 2004-2015. Figs (5 and 6) show the results of the relationships of the observed crop yields vs. the simulated ones, under the investigated irrigation scheduling scenarios (as listed in tables 6 and 7). As a general trend, the relationships between the observed and simulated yields were strong under all the investigated irrigation scenarios, with excellent NRMSE values less than $10 \%$.

For the wheat crop, the better simulation results were observed with applying six irrigation events instead of five events under Sakha region. The best wheat simulation result was observed under the "Wh_Irr8" scenario that has fixed irrigation intervals of 26 days and a fixed application depth of $80 \mathrm{~mm}$ (with $8.70 \%$ NRMSE). Whereas, the better simulation results of maize crop were observed with applying 
seven irrigation events instead of six events. Scenarios "Mz_Irr5" and "Mz_Irr6" gave the lowest NRMSE values of 3.89 and $3.86 \%$, while the second one saves about 90 $\mathrm{mm} /$ season.

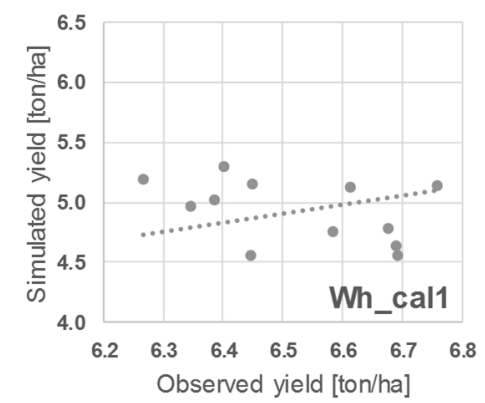

RMSE $=1.631$ ton $/$ ha, NRMSE $=25.0 \%$

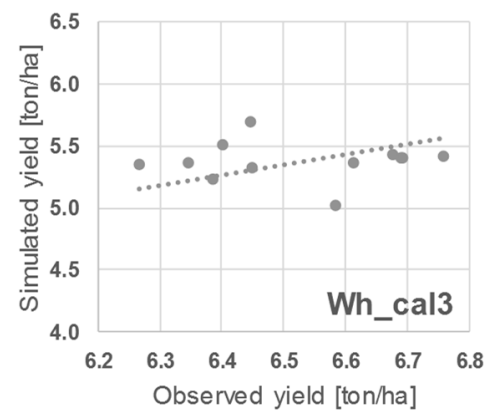

$\mathrm{RMSE}=1.171$ ton/ha, NRMSE $=17.9 \%$

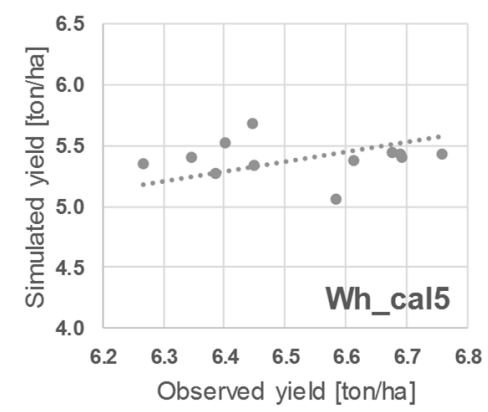

$\mathrm{RMSE}=1.153$ ton/ha, NRMSE $=17.7 \%$

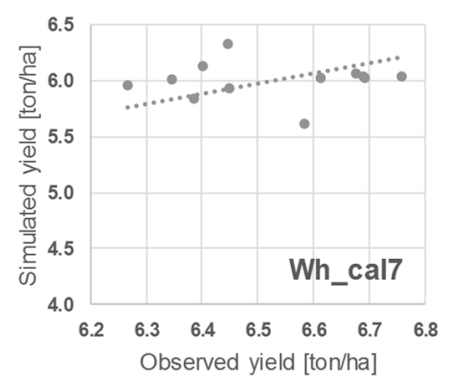

$\mathrm{RMSE}=0.570$ ton $/ \mathrm{ha}, \mathrm{NRMSE}=8.7 \%$

Fig. 3. Results of the simulated yield of the AquaCrop model to observe wheat yield in Sakha region during the period 2004-2015. 


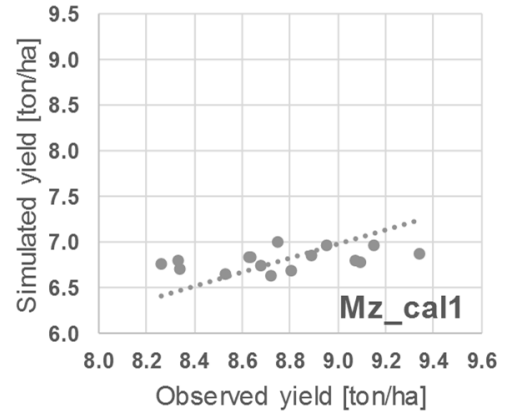

RMSE $=1.974$ ton $/$ ha, NRMSE $=22.5 \%$

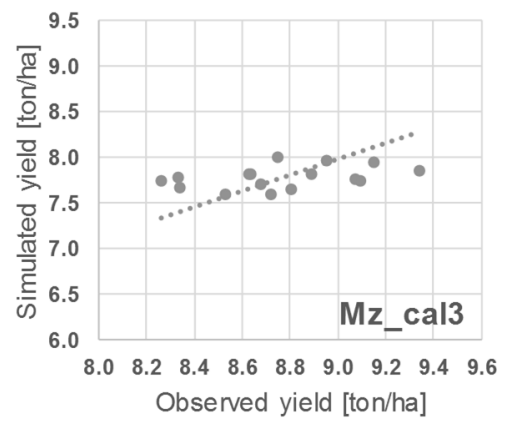

$\mathrm{RMSE}=1.020$ ton $/$ ha, NRMSE $=11.6 \%$

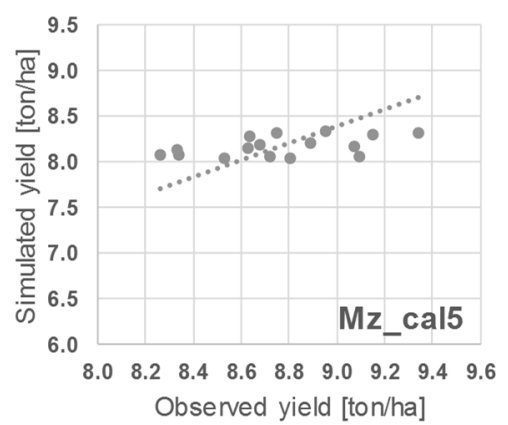

RMSE $=0.650$ ton $/$ ha, NRMSE $=7.4 \%$

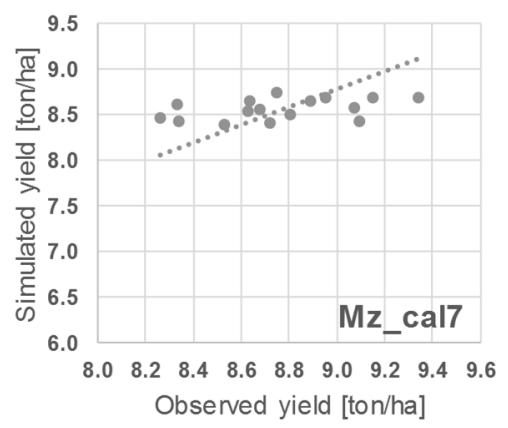

RMSE $=0.338$ ton $/$ ha, NRMSE $=3.9 \%$

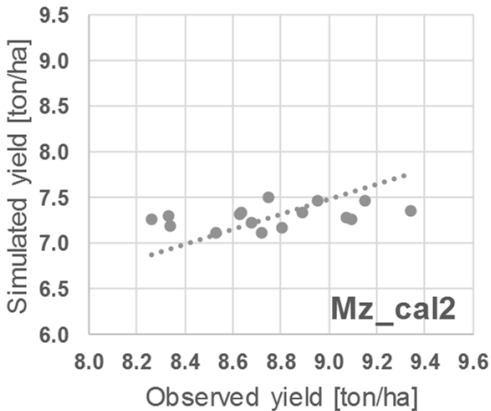

RMSE $=1.494$ ton $/$ ha, NRMSE $=17.0 \%$

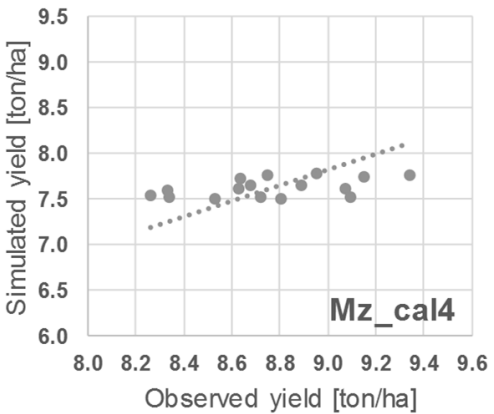

RMSE $=1.168$ ton $/$ ha, NRMSE $=13.3 \%$

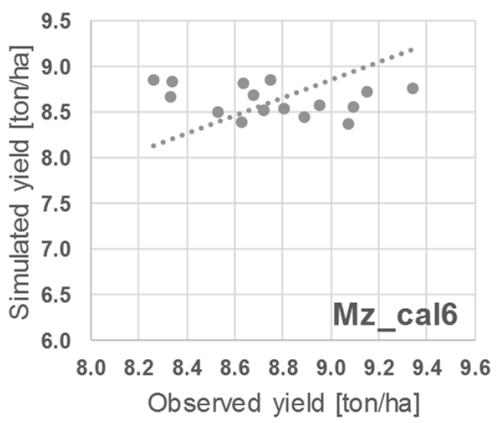

RMSE $=0.400$ ton $/$ ha, NRMSE $=4.6 \%$

Fig.4. Results of the simulated yield of the AquaCrop model to observe maize yield in Sakha region during the period 2000-2015. 


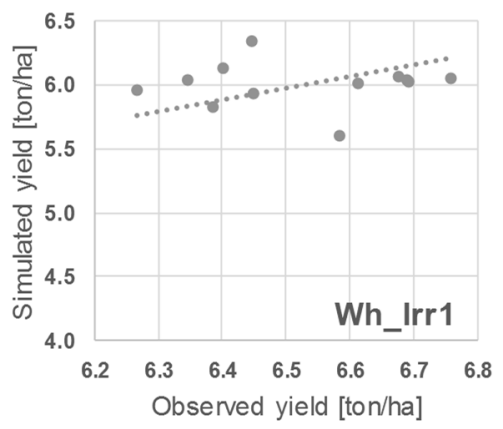

$\mathrm{RMSE}=0.571$ ton $/ \mathrm{ha}, \mathrm{NRMSE}=8.75 \%$

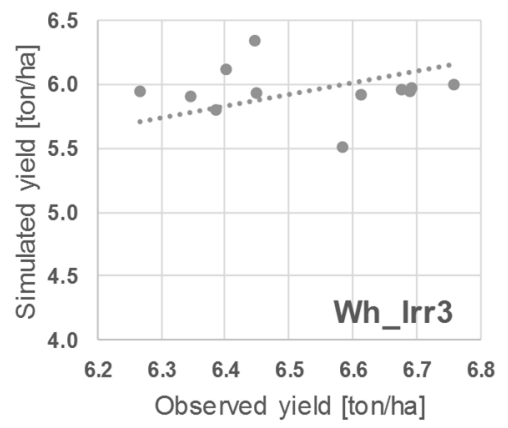

RMSE $=0.635$ ton $/$ ha, NRMSE $=9.73 \%$

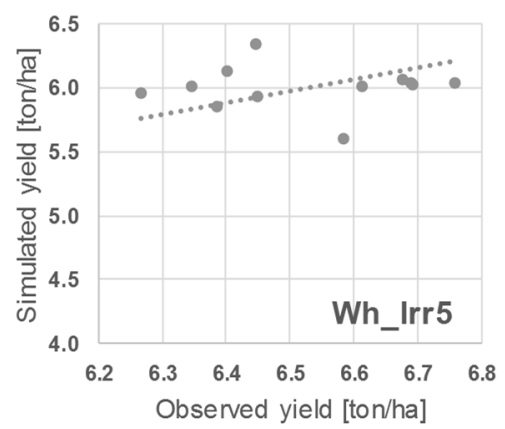

$\mathrm{RMSE}=0.572$ ton $/$ ha, $\mathrm{NRMSE}=8.76 \%$

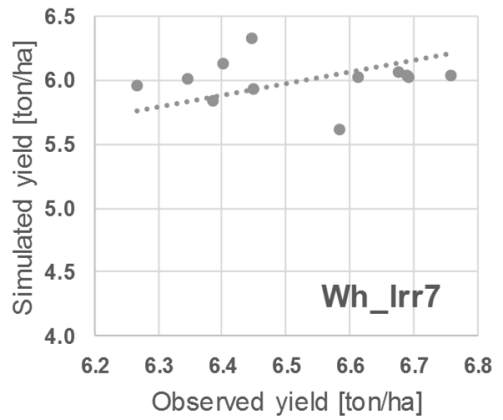

$\mathrm{RMSE}=0.570$ ton/ha, NRMSE $=8.73 \%$

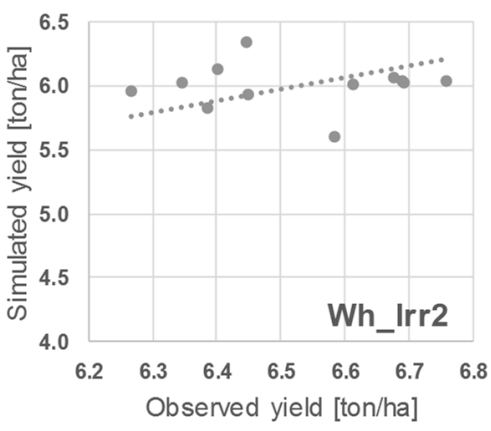

RMSE $=0.574$ ton $/$ ha, NRMSE $=8.80 \%$

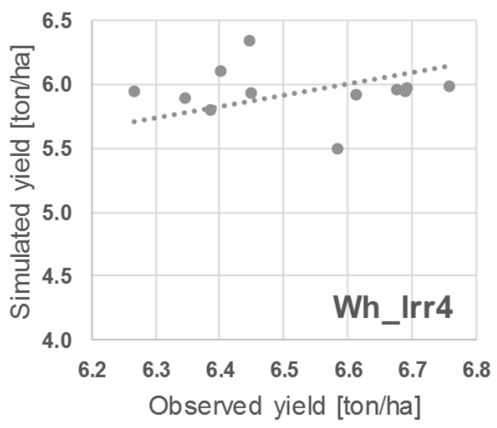

RMSE $=0.637$ ton/ha, NRMSE $=9.76 \%$

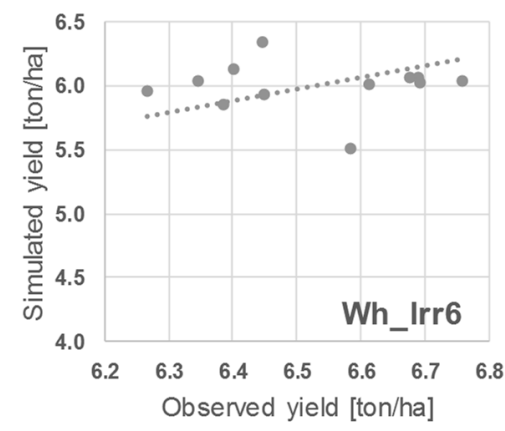

$\mathrm{RMSE}=0.583$ ton/ha, NRMSE $=8.94 \%$

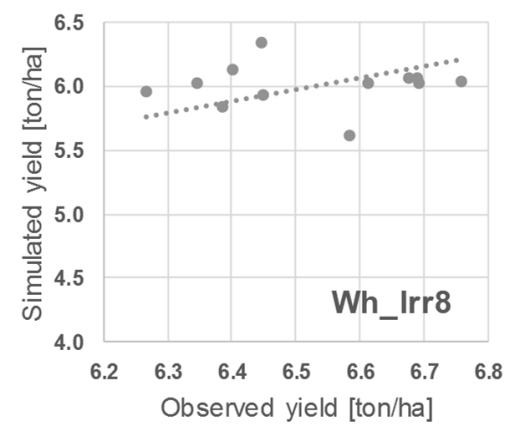

$\mathrm{RMSE}=0.568$ ton/ha, NRMSE $=8.70 \%$

Fig.5. The effect of irrigation schedule scenarios in the simulation of wheat crop yield by using AquaCrop model (For Sakha region during the period 2004-2015). 


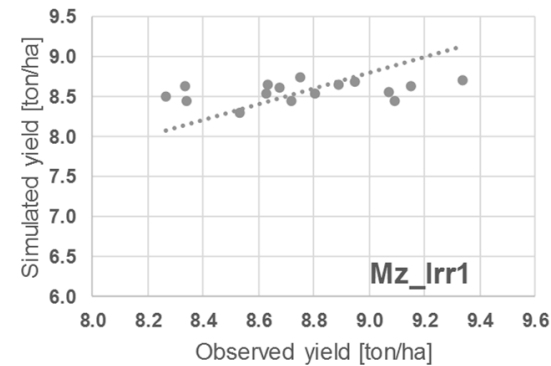

RMSE $=0.348$ ton $/$ ha, NRMSE $=3.91 \%$

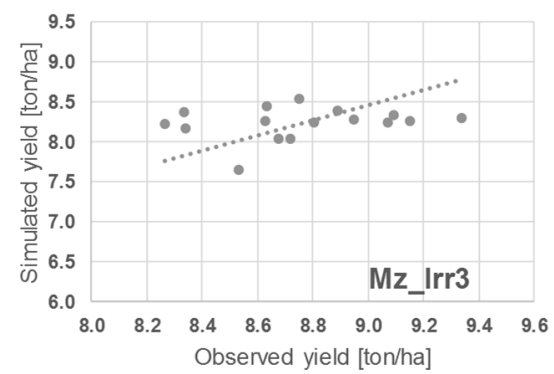

RMSE $=0.623$ ton $/$ ha, NRMSE $=7.30 \%$

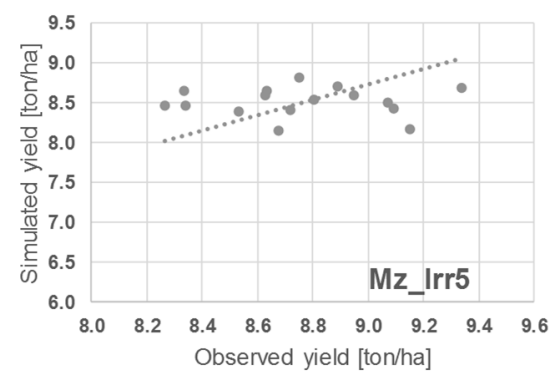

RMSE $=0.341$ ton $/$ ha, NRMSE $=3.89 \%$

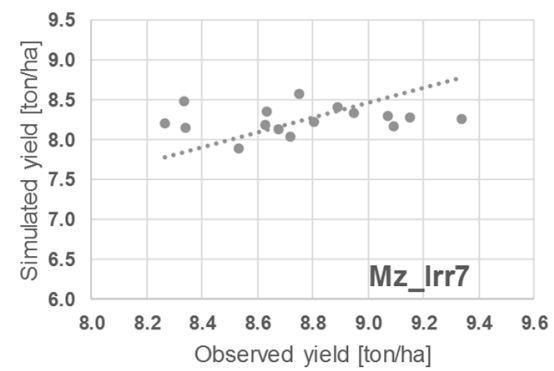

$\mathrm{RMSE}=0.0 .581$ ton/ha, NRMSE $=$ $6.60 \%$

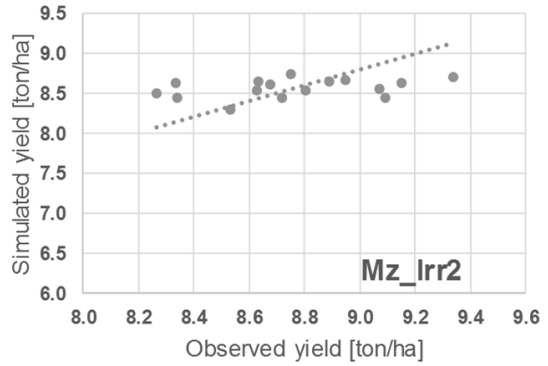

$\mathrm{RMSE}=0.342$ ton/ha, NRMSE $=3.90 \%$

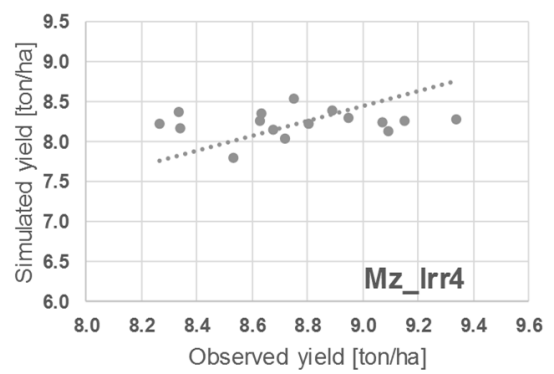

RMSE $=0.619$ ton/ha, NRMSE $=7.07 \%$

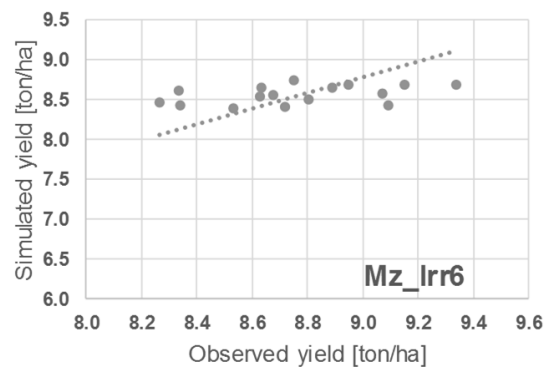

RMSE $=0.338$ ton $/$ ha, NRMSE $=3.86 \%$

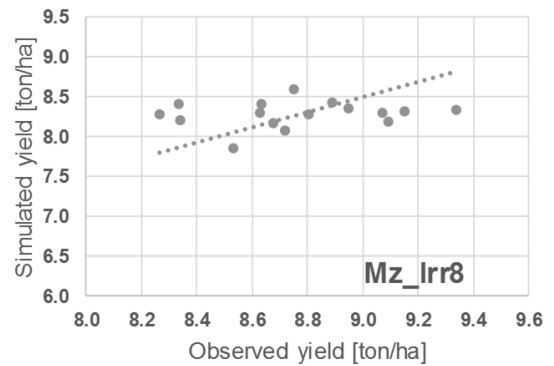

RMSE $=0.577$ ton $/$ ha, NRMSE $=6.58 \%$

Fig.6. The effect of irrigation schedule scenarios in the simulation of maize crop yield by using AquaCrop model (For Sakha region during the period 2004-2015).

\section{CONCLUSION}

Several studies reflected the ability of the AquaCrop model to provide solid and accurate modeling simulations of different agricultural systems under water limiting conditions. Although the model has already been tested and applied in various regions, efforts are continuously taken to further improve the simulations of the crop 
yields and water use by introducing new systems boundaries and local conditions, without affecting the simple approach of the model and the transparency of the simulation. The current study evaluated the performance of AquaCrop model in simulating the production of wheat and maize crops in old lands in the Nile valley and the Delta region of Egypt, by using fully irrigated system. Through the calibration process, the best crop growth parameters of wheat and maize were identified, which improved the relationship between the observed and the simulated crop yield by NRMSE of $8.7 \%$ and $3.9 \%$, for wheat and maize respectively. The calibration was based only in crop yield as an indicator of the comparison. AquaCrop model have the ability to conduct a calibration for a given crop by using other indicators besides the crop yield, such as the canopy cover curve of the crop, the water balance indicator, and the final above-ground biomass. In the current study, the actual data records of the studied crops didn't include any records relevant to the previous indicators, which led to focusing the calibration process in the crop yield only. It's recommended to improve the field data records, to include those indicators in order to improve the quality of the calibration and improve the simulation performance under the Egyptian conditions.

In Addition to, the model reflected a good performance in evaluating some irrigation scheduling scenarios, which may be applied by the farmers. Those simulations reflected the effect of the irrigation scheduling different parameters on the crops yield production.

In conclusion, this calibration process is a step to further applications of AquaCrop model as a simulation tool in supporting the agricultural decisions planning, in order to face the current and future challenges of water shortage and irrigation systems improvement. Noting that, further validation studies under real conditions will be necessary. Also, other studies relative to economic and environmental analysis should be performed in future to support appropriate decisions.

\section{ACKNOWLEDGMENT}

This work is a part of the national assessment of the impact of climate change on the crops productivity in Egypt, which is a part of the report of the implementation of Component-I of the Project "Promoting Food and Water Security in the Arab Region: Enhancing National Capacities on Assessment of Climate Change and Water Variability on Agricultural Productivity. The project is under organization of ESCWA, FAO and ACSAD.

\section{REFERENCES}

1. Allam M.N., F.El Gamal, and M.Hesham Irrigation systems performance in Egypt. In : Lamaddalena N. (ed.), Lebdi F. (ed.), Todorovic M. (ed.), Bogliotti C. (ed.). Irrigation systems performance. Bari: CIHEAM, 2005. p. 85-98 (Options Méditerranéennes : Série B. Etudes et Recherches; n. 52). 
2. Allen, R.G., L.S. Pereira, D. Raes, M.Smith, 1998. Crop evapotranspiration: guidelines for computing crop water requirements. In: FAO Irrigation and Drainage Paper No. 56. FAO, Rome, Italy, 300 p.

3. Attaher, S. M., N.Zaki, and M.Karrou, 2013. "WP-Optimizer" to improve water productivity in irrigated agriculture in Egypt. Proc. Of The 1st CIGR inter-regional conference on land and water challenges entitled "Water, Environment and Agriculture: challenges for sustainable development". Bari, Italy.

4. Behera, S.K., R.K.Panda, 2009. Integrated management of irrigation water and fertilizers for wheat crop using field experiments and simulation modeling. Agric. Water Manag. 96: 1532-1540.

5. Bird, D. N., S. Benabdallah, N.Gouda, F.Hummel, J.Koeberl, I.La Jeunesse, and S.Woess-Gallasch, (2015). Modelling climate change impacts on and adaptation strategies for agriculture in Sardinia and Tunisia using AquaCrop and value-atrisk. Science of The Total Environment, 543, 1019-1027.

6. Bulatewicz, T., W. Jin, S.Staggenborg, S.Lauwo, M.Miller, S.Das, D.Andresen, J.Peterson, D.R.Steward, S.M.Welch, 2009. Calibration of a crop model to irrigated water use using a genetic algorithm. Hydrol. Earth Syst. Sci. 13, 14671483.

7. Domínguez, A., J. M.Tarjuelo, J. A.de Juan, E.López-Mata, J.Breidy, and F.Karam, (2011). Deficit irrigation under water stress and salinity conditions: The MOPECOSalt Model. Agricultural Water Management, 98(9):1451-1461.

8. El-Agha, D. E., D. J. Molden, and A. M.Ghanem, (2011). Performance assessment of irrigation water management in old lands of the Nile delta of Egypt. Irrigation and Drainage Systems. doi:10.1007/s10795-011-9116-z

9. Fawzi, A. M., 2009, Effect of Soil Compaction on Tractor Performance. Ph.D. Thesis, Fac. of Agric., Mansoura Univ.

10. Hassanein, M. K. and M.A.Medany, 2007. The impact of climate change on production of maize (Zea Mays L.). International Conference on Climatic Changes and their Impacts on Coastal Zones and River Deltas: Vulnerability, Mitigation and Adaptation, April 23-25, 2007, Alexandria, Egypt, p: 271 -288.

11. Ibrahim, M.M., S.A. Ouda, A. Taha, G. El Afandi and S.M. Eid. 2012. Water management for wheat grown in sandy soil under different climate change scenarios. J. of Soil Sci. and Plant Nut.12(2):195-210.

12. Jagtap, S.S., and J.W.Jones, 2002. Adaptation and evaluation of the CROPGROsoybean model to predict regional yield and production. Agric. Ecosyst. Environ. 93: 73-85

13. Katerji, N., P.Campi, and M.Mastrorilli. 2013. Productivity, evapotranspiration, and water use efficiency of corn and tomato crops simulated by AquaCrop under contrasting water stress conditions in the Mediterranean region. Agricultural Water Management, 130:14-26 
14. Khalil, F.A., H.Farag, G. El Afandi, and S. A.Ouda, 2009. Vulnerability and adaptation of wheat to climate change in Middle Egypt. 13th International Conference on Water Technology. Hurghada, Egypt. 12-15 March.

15. MALR, 2000-2016. Agricultural statistics. Economic Affairs Sector. Ministry of Agriculture and Land Reclamation. Egypt.

16. MALR, 2015. Food balance study of Egypt. Economic Affairs Sector. Ministry of Agriculture and Land Reclamation. Egypt.

17. MWRI, 2017. Annual statistics of water resources. Ministry of water resources and irrigation, Egypt

18. Reidsma, P., F.Ewert, A.Oude Lansink, and R. Leemans, 2010. Adaptation to climate change and climate variability in European agriculture: the importance of farm level responses. Eur. J. Agron. 32: 91-102.

19. Salemi, H., M.Amin, M.Soom, T. S.Lee, S. F. Mousavi, A.Ganji, and Kamilyusoff, M. (2011). Application of AquaCrop model in deficit irrigation management of Winter wheat in arid region, 610: 2204-2215.

20. Saxton, K.E. 1985. Soil water hydrology: Simulation for water balance computations. IAHS Pub. No. 148: 47-59

21. Saxton, K. E. and P. H. Willey. 2006. The SPAW Model for Agricultural Field and Pond Hydrologic Simulation. Chapter 17 in: Mathematical Modeling of Watershed Hydrology, V. P. Singh and D. Frevert, Editors; CRC Press, p 401-435.

22. Soliman, I. J. F.Fabiosa, M. G.Amer, and S.Kandil, (2010). Impacts of the economic reform program on the performance of the Egyptian agricultural sector, Working paper ; 10-WP 509. Center for Agricultural and Rural Development. Iowa State University

23. Steduto, P., D. Raes, T. C. Hsiao, E. Fereres, L. Heng, G. Izzi, and J. Hoogeveen 2008. AquaCrop: a new model for crop prediction under water deficit conditions, Options Mediterranean's, Series A, No. 80.

24. Toumi, J., S. Er-Raki, J. Ezzahar, S.Khabba, L.Jarlan, and A.Chehbouni. 2016. Performance assessment of AquaCrop model for estimating evapotranspiration, soil water content and grain yield of winter wheat in Tensift Al Haouz (Morocco): Application to irrigation management. Agricultural Water Management, 163:219235.

25. You, L., M.W. Rosegrant, S.Wooda, and D.Sun, 2009. Impact of growing season temperature on wheat productivity in China. Agric. For. Meteorol. 149: 10091014.

26. Vanuytrecht, E., D. Raes, P.Steduto, T. C.Hsiao, E. Fereres, L. K.Heng, and P.Mejias Moreno. 2014. AquaCrop: FAO's crop water productivity and yield response model. Environmental Modelling and Software, 62:351-360. 


\section{تقييم أداء "AquaCrop" لمحاكاة انتاج محاصيل القمح و الأذرة الثامية فى مصر}

$$
\begin{aligned}
& \text { أمل ابو المجد عبد الباقى1، ايهاب جناد²، مازن نعمان2، ديرك ريس3 } \\
& \text { 1. معهد بحوث الهنسة الزراعية - مركز البحوث الزراعية - مصر } \\
& \text { 2. المركز العربي لدراسات المناطق الجافة والأراضي القاحلة (أكساد) } \\
& \text { 3. كلية هندسة العلوم الحيوية - جامعة لوفين - بلجيكا }
\end{aligned}
$$

تهدف الدراسة الى تقييم أداء نموذج AquaCrop فى محاكاة انتاجية محصولى القمح و الذرة الثنامية بالأراضى القديمة، بوادى و دلتا النيل بمصر، تحت نظام الرى الدائم. تم استخدام بيانات حقلية لسنوات متعددة للفترة 2000-2016، لمعاييرة قدرة النموذج على محاكاة الإنتاجية المحصولية لمحاصيل الدراسة. و قد نم ثقييم أداء النموذج باستخدام جذر متوسط مربع الخطأ لعان العيارى (NRMSE). و قد كانت قيمة NRMSE لأفضل ملفات المحاصيل المعاييرة 8.7\% و 3.9 \% لمحصولى القمح و الذرة الثامية على الترتيب، و المحسوبة للعلاقة بين الإنتاجية المحصولية المقاسة

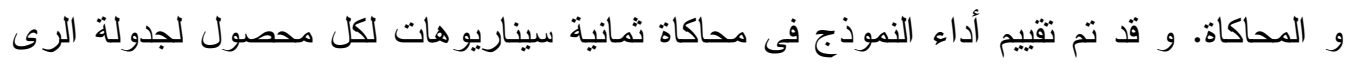
الحقلى، و النى من المحتمل أن يطقةها المزارعون. و قد أبدى النموذج أداء جيد فى محاكاة هذه

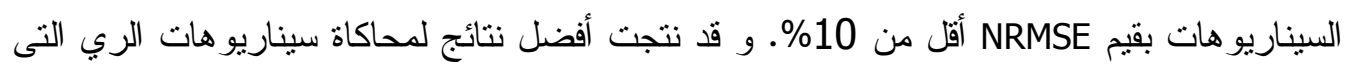
تحتوى على ستة و سبع ريات خلال الموسم لكل من القمح و الذرة الثامية على الترتيب. و تعتبر عملية المعاييرة التى ثم إجر ائها بهذه الدراسة، خطوة فى سبيل استخدام نموذج AquaCrop كأداة للمحاكاة و تخطيط القرارت الزراعية، بهدف مواجهة التحديات الحالية لنقص المياه و منطلبات نطوير نظم الرى. 